\title{
AMELIORATION OF ALKALIZED SOLONCHAK SOILS BY SUBSURFACE GRAVEL BLIND DITCHES AND DESULFURIZED GYPSUM
}

\author{
WANG, X. $.^{1,2}-$ SUN, Z. J. ${ }^{2,3,4,5^{*}}-$ LIU, X. J. ${ }^{1}-$ BAO, Z. Y. ${ }^{1}-$ JIAO, B. Z. ${ }^{2}-$ LI, X. Q. ${ }^{2}-$ ZENG, Y. X. ${ }^{2}$ \\ - SAMEH, E. ${ }^{6}$ \\ ${ }^{I}$ The Scientific Research Institute of the Water Conservancy of Ningxia, \\ Yinchuan 750021, Ningxia, China \\ ${ }^{2}$ School of Civil Engineering and Hydraulic Engineering, Ningxia University, \\ Yinchuan 750021, Ningxia, China \\ ${ }^{3}$ School of Resources and Environmental Science, Ningxia University, \\ Yinchuan 750021, Ningxia, China
}
${ }^{4}$ Ningxia Key Laboratory of Resources Assessment and Environmental Regulation in Arid Regions, Yinchuan 750021, Ningxia, China

${ }^{5}$ China-Arab Joint International Research Laboratory for Featured Resources and Environmental Governance in Arid Region, Yinchuan 750021, Ningxia, China

${ }^{6}$ Vegetable Research Department, Agricultural and Biological Division, National Research Centre, Dokki, Giza 12311, Egypt

*Corresponding author

e-mail:sunzhaojunyx@126.com

(Received 23 $3^{\text {rd }}$ Feb 2019; accepted $3^{\text {rd }}$ May 2019)

\begin{abstract}
This study aims to investigate the subsurface gravel ditches and desulfurization gypsum (DG) as amelioration methods for alkalized solonchak soils in Gansu Jingyuan of China $\left(37^{\circ} 02^{\prime} \mathrm{N}, 104^{\circ} 96^{\prime}\right.$ E). Three blind ditch spacing $(6,9$ and $12 \mathrm{~m})$ and three application rates of desulfurization gypsum $\left(20,22\right.$ and $\left.24 \mathrm{t} / \mathrm{hm}^{2}\right)$ were used to alkalized solonchak soil and increasing the yield of Chinese wolfberry (Lycium bararum L.), as compared with the control treatments without blind ditch and DG. The findings show that a larger blind ditch density and appropriate DG application rate contributes to discharge salts easily by reducing the migration distance for soil solutes moving. Under the treatment with blind ditches with 6-metre spacing and a $22 \mathrm{t} / \mathrm{hm}^{2}$ DG application rate, the values of $\mathrm{pH}$, exchangeable sodium percentage (ESP) and electrical conductivity (EC) of the soil layer up to $40 \mathrm{~cm}$ from the surface were decreased by $11.0 \%, 38.1 \%$ and $34.5 \%$, respectively, than those of the control which had no blind ditch and DG treatment in the first year. The yield of Chinese wolfberry was increased by $228.8 \%$ than that of the control in the second year.
\end{abstract}

Keywords: alkalinity, irrigation, leaching, soil salinity, alkalized solonchak

\section{Introduction}

Saline-sodic soils cover an extensive land surface around the world (Qadir and Oster, 2004). One particular form of these soils is alkalized solonchak which is characterized by an excessively high concentration of sodium with high $\mathrm{pH}$ on the surface (Feng et al., 2017). According to a study (Kameli, 2017), the alkalized solonchak mainly distributes in Liaoning, Gansu and Xinjiang province of China.

Solonetz is also found in other regions such as central Asia and central Australia as well as patches in other continents (Driessen et al., 2000). The area of alkalized solonchak in 
Gansu is approximately $21.18 \times 10^{4} \mathrm{hm}^{2}$ (Lin et al., 2016). The amelioration of saline-sodic requires a complex and long-term practice (Zhang et al., 2012a). The particles of this type of soils are dispersed and swelled after irrigation, causing the pores to close (Chi and Wang, 2014), which makes it difficult to be rapidly leached. Soluble salts accumulated in the soil surface cause changes in soil physical and chemical properties (Vance, 2008), which directly affect its ability for providing water, air and nutrients to plants (Heng et al., 2018) which is one of the main factors restricting the local agricultural production and ecological improvement.

The key to the amelioration of alkali soils is improving soil physical and chemical properties, providing a suitable soil environment for crops (De et al., 2014; Sakai et al., 2011). Presently, there are published reports on the amelioration of alkali soils with measures including planting saline-alkali tolerant crops (Mohsenian and Roosta, 2015), soil improvement by applying desulfurization gypsum (DG) (Mao et al., 2016), drip irrigation (Chen et al., 2015) and straw mulching etc (Xue et al., 2014). However due to a lower permeability of the alkalized solonchak soil, the leached salts from the upper layer may accumulate in the deeper layer resulting in secondary salinization occasionally, and in some cases the long improvement time and high cost make any single amelioration technique impractical and difficult to be extended.

The key ingredient in DG is $\mathrm{CaSO}_{4}$ (Sakai et al., 2004), which increases $\mathrm{Ca}^{2+}$ concentration in the soil once it is applied. As the $\mathrm{Ca}^{2+}$ capacity of adsorption to soil colloids is stronger than that of $\mathrm{Na}^{+}$and the adsorbed $\mathrm{Na}^{+}$on soil colloids can exchange with $\mathrm{Ca}^{2+}$ in the soil solution, the increase in the $\mathrm{Na}^{+}$concentration in the soil solution results in an increase in alkalinity which damages soil aggregates. For this reason any improvement in soil aggregates and texture can effectively improve soil physical and chemical properties (Yu et al., 2015; Rhoton and McChesney, 2011).

Other experiments for the amelioration of saline-sodic show that the application of DG can decrease the soil $\mathrm{pH}$ and exchangeable sodium percentage (ESP) remarkably, but there is a problem associated with salt deposition within $60 \mathrm{~cm}$ of the soil layer (Lin et al., 2016). Due to the lower permeability of alkalized solonchak, the salts leached from the surface do not effectively discharge out of the soil, and instead they move to the land surface during evaporation. To facilitate salt leaching, mechanical means are effective which include the underground drainage facility to accelerate soil water movement and promote leaching of salts (Min, 2014; Christen and Skehan, 2001). The blind ditch is one form of underground drainage facilities which has advantages with a long lifespan and the benefit to farming operations without blocking the land surface (Pan and Zhao, 1998).

The blind ditches, backfilled with materials including straw and gravels etc., can accelerate infiltration of water and discharge saline water (Tao et al., 2016). It also allows soil water to dissolve salts sufficiently and drain it out of the soil through the blind ditches to reduce soil salinity/alkalinity which is an advantage over the traditional treatments that cannot discharge salts from the soil (Yu et al., 2012). The published research findings (Yang et al., 2015b) suggest that the blind ditch treatment on low-lying saline land with a clay layer can improve the soil permeability, increase the internal drainage ability and accelerate the salt mobility in the soil, resulting in a better leaching of ions such as $\mathrm{Na}^{+}, \mathrm{SO}_{4}^{2-}$ , and $\mathrm{Cl}^{-}$in the soil. Chinese wolfberry (Lycium barbarum) belongs to deciduous shrub with a high degree of economic value and medicinal value. It is mainly distributed in arid and semi-arid regions of northwest China. It has the characteristics of salt and drought tolerance and is very suitable to plant in saline-alkali soils (Liu et al., 2015). 
At present, the blind ditch is used in Ningxia (Pan and Zhao, 1998) and on coastal saline soils in Jiangsu in China (Yang et al, 2015b). There are extensive reports on the amelioration of alkali soils through the application of DG (Sakai et al., 2011; Yu et al., 2015), but there are few published reports about the effects of blind ditches combined with DG on the physical and chemical properties of alkalized solonchak and ions. Research on the amelioration effects of alkalized solonchak on the spacing of blind ditches and the application rate of DG is still needed to apply this method more efficiently and cost effectively. The present study examines the application of DG and blind ditches on a farmland using gravels and straw as backfilling materials to investigate the effects on subsurface physical and chemical properties of alkalized solonchak in Gansu, China. The concentrations of salt ions and the yield of Chinese wolfberry under different treatments are examined. The outcomes of this study can provide a theoretical and technical guidance for the amelioration and utilization of alkalized solonchak in China.

\section{Materials and methods}

\section{Site characterization}

The experimental site is located in Dongsheng, Jingyuan county, Gansu Province $\left(37^{\circ} 03^{\prime} \mathrm{N}, 104^{\circ} 96^{\prime} \mathrm{E}\right)$, China. The climate is typically arid continental with mean annual precipitations of $240 \mathrm{~mm}$, which is mainly concentrated between July and September, and mean annual evaporation of $1,634 \mathrm{~mm}$, up to 6-7 times the annual average precipitations. Annual average temperature is $9^{\circ} \mathrm{C}$. Seasonal drought is frequent in spring, the soluble salts accumulate in the upper soil profile during spring. The groundwater level changes from 1.3 to $1.8 \mathrm{~m}$. The soil organic matter ranges from 5.12 to $8.97 \mathrm{~g} / \mathrm{kg}$, available nitrogen from 17.52 to $29.25 \mathrm{mg} / \mathrm{kg}$, available P from 0.7 to $5.98 \mathrm{mg} / \mathrm{kg}$, available K from 179.64 to $244.58 \mathrm{mg} / \mathrm{kg}$. Other physical and chemical properties of the soil are listed in Table 1. Data in Table 1 show that EC in the surface soil gradually decreases with the soil depth. ESP is over $21 \%$ and $\mathrm{pH}$ is above 8.5 . The primary cation in the top $100 \mathrm{~cm}$ of the soil is $\mathrm{Na}^{+}$ion, whereas the primary anion is $\mathrm{Cl}^{-}$ion.

Table 1. Main physical and chemical properties of tested soils

\begin{tabular}{|c|c|c|c|c|c|c|c|c|c|c|c|c|}
\hline \multirow{2}{*}{$\begin{array}{l}\text { Depth } \\
\text { cm }\end{array}$} & \multicolumn{8}{|c|}{$\begin{array}{c}\text { Ion ingredients } \\
\mathrm{cmol} / \mathrm{kg}\end{array}$} & \multirow{2}{*}{ pH } & \multirow{2}{*}{$\begin{array}{c}\mathbf{E C} \\
\mathrm{dS} / \mathbf{m}\end{array}$} & \multirow{2}{*}{$\begin{array}{c}\text { ESP } \\
\%\end{array}$} & \multirow{2}{*}{$\begin{array}{l}\text { Bulk } \\
\text { density } \\
\mathrm{g} \cdot \mathrm{cm}^{-3}\end{array}$} \\
\hline & $\mathbf{N a}^{+}$ & $\mathrm{Ca}^{2+}$ & $\mathbf{K}^{+}$ & $\mathrm{Mg}^{2+}$ & $\mathrm{CO}_{3}^{2-}$ & $\mathrm{HCO}_{3}^{-}$ & $\mathrm{Cl}^{-}$ & $\mathbf{S O}_{4}^{2-}$ & & & & \\
\hline $0-20$ & 4.21 & 0.27 & 0.08 & 0.23 & 1.19 & 1.01 & 1.42 & 1.25 & 9.1 & 2.89 & 28.5 & 1.52 \\
\hline $20-40$ & 3.44 & 0.33 & 0.09 & 0.20 & 1.02 & 0.84 & 1.19 & 1.02 & 8.8 & 2.72 & 24.8 & 1.57 \\
\hline $40-60$ & 2.78 & 0.31 & 0.07 & 0.31 & 0.88 & 0.72 & 0.65 & 0.84 & 8.6 & 1.83 & 22.5 & 1.62 \\
\hline $60-80$ & 2.22 & 0.28 & 0.08 & 0.25 & 0.67 & 0.54 & 0.54 & 0.72 & 8.5 & 1.32 & 21.1 & 1.68 \\
\hline $80-100$ & 1.15 & 0.24 & 0.06 & 0.22 & 0.52 & 0.32 & 0.31 & 0.68 & 8.5 & 1.02 & 21.9 & 1.67 \\
\hline
\end{tabular}

Soil pH was measured using a Mettler Toledo S220-K pH meter. Soil EC value was measured using a Mettler Toledo S230. Exchangeable $\mathrm{Na}^{+}$was measured using an ammonium acetate-ammonium hydroxide-flam photometric method, and ESP was calculated as the percentage of exchangeable $\mathrm{Na}^{+}$and cation exchange capacity (CEC). The concentrations of $\mathrm{K}^{+}$and $\mathrm{Na}^{+}$were measured with a subtraction method. $\mathrm{Ca}^{2+}$ and $\mathrm{Mg}^{2+}$ were measured using the Ethylene Diamine Tetraacetic Acid (EDTA) titration 
method. $\mathrm{Cl}^{-}$was measured using $\mathrm{AgNO}_{3}$ titration. $\mathrm{SO}_{4}^{2-}$ was measured using the EDTA back-dropping method, and $\mathrm{CO}_{2}^{-3}$ and $\mathrm{HCO}^{-3}$ were measured using double indicator titration (Bigham, 1965). The application process is shown in Figure 1.
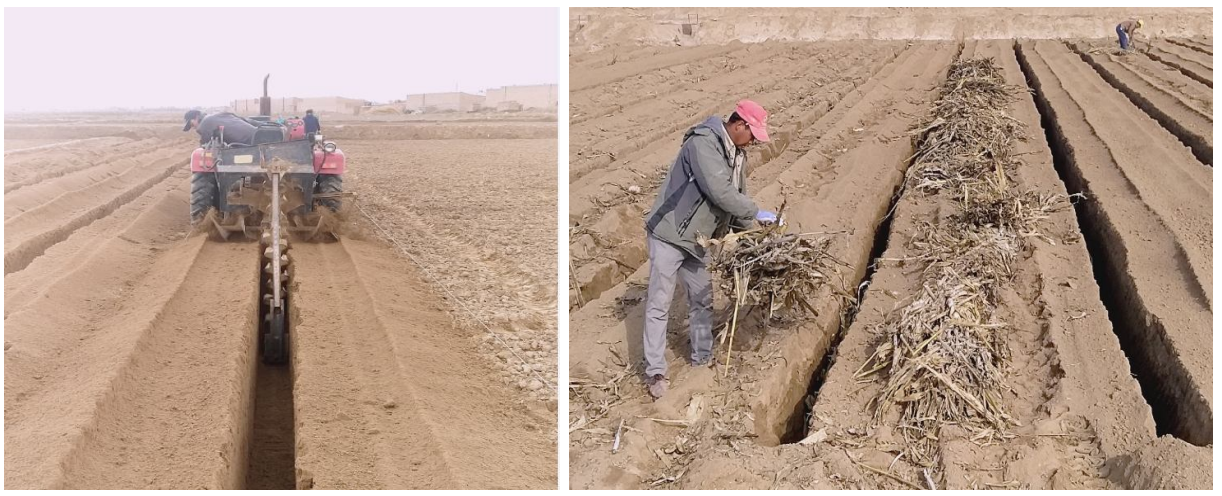

Figure 1. Blind ditch and laying cushion

\section{Experimental design}

The research was carried out between 2016 and 2017 with a unified leaching quota of $4.5 \times 10^{3} \mathrm{~m}^{3} / \mathrm{hm}^{2}$ (Yang et al., 2015a). According to previous reports (Yang et al., 2015b) and known characteristics of alkalized solonchak, three blind ditches were set up at spacing of $6 \mathrm{~m}, 9 \mathrm{~m}$ and $12 \mathrm{~m}$, respectively. In this study, the spacing is the horizontal distance between two blind ditches. Three application rates were used at $20 \mathrm{t} / \mathrm{hm}^{2}$, $22 \mathrm{t} / \mathrm{hm}^{2}$ and $24 \mathrm{t} / \mathrm{hm}^{2}$. A site without the blind ditch and DG was as the control site (CK), each treatment was repeated 3 times. The experimental design is shown in Table 2.

Table 2. Experimental design

\begin{tabular}{c|c|c}
\hline Treatments & $\begin{array}{c}\text { Blind ditch spacing } \\
\mathbf{m}\end{array}$ & $\begin{array}{c}\text { Desulfurized gypsum application rate } \\
\mathbf{t} / \mathbf{h m}^{\mathbf{2}}\end{array}$ \\
\hline CK & Non & Non \\
T1 & 6 & 20 \\
T2 & 6 & 22 \\
T3 & 6 & 24 \\
T4 & 9 & 20 \\
T5 & 9 & 22 \\
T6 & 9 & 24 \\
T7 & 12 & 20 \\
T8 & 12 & 22 \\
T9 & 12 & 24 \\
\hline
\end{tabular}

CK means the control treatment

Ditches were dug with a ditching machine (Chain, CASE860) with a width of $30 \mathrm{~cm}$ and depth of 90 to $120 \mathrm{~cm}$ which have a slope gradient of $1 \%$ from the field to the drain. Gravels were laid at the bottom of each ditch with $20 \mathrm{~cm}$, and then covered with $40 \mathrm{~cm}$ of straw as a filter, and finally backfilled with soils. The blind ditches were dug perpendicular to the drain 
which was deeper than the ditch. Sheep manure was applied at a rate of $45 \mathrm{t} / \mathrm{hm}^{2}$ uniformly at each site. According to the experimental design DG was applied between different treatments. Deep tillage was then performed to guarantee sufficient mixing. According to the previous studies (Yang et al., 2015a), the salts in the soil should to leach in total 3 times, the volume of leached water after the first operation was $1 / 2$ of the leaching quota (ca. $2,250 \mathrm{~m}^{3} / \mathrm{hm}^{2}$ ) and the leached water was immersion for $24 \mathrm{~h}$ and then drained off the land surface. The volume of leached water after the second operation was $1 / 3$ of the leaching quota (ca. $1,500 \times 10^{3}$ $\mathrm{m}^{3} / \mathrm{hm}^{2}$ ) and the leached water was immersion for $48 \mathrm{~h}$ and then drained off the land surface. Finally, the volume of leached water after the third operation was $1 / 6$ of the leaching quota $\left(750 \mathrm{~m}^{3} / \mathrm{hm}^{2}\right)$. Chinese wolfberry seedlings were planted on 26 April 2016 with row spacing of $2.0 \mathrm{~m}$ and plant spacing of $1.5 \mathrm{~m}$. The planted sites were irrigated once, respectively, during the May to November with $1.2 \times 10^{3} \mathrm{~m}^{3} / \mathrm{hm}^{2}$ (irrigation quota) water at every month.

\section{Experimental methods}

In order to analyze the amelioration effects, the soil samples were collected before the ditches were dug on 5 April 2016 and on 25 April 2016 in the first year, and on 25 April 2017 in the second year. Based on the principle of randomness and multipoint mixture, soil samples were collected using an auger by a random method in layers with spacing of $20 \mathrm{~cm}$ from the land surface. Samples were collected at 0 to $20 \mathrm{~cm}, 20$ to $40 \mathrm{~cm}, 40$ to $60 \mathrm{~cm}, 60$ to $80 \mathrm{~cm}$, and 80 to $100 \mathrm{~cm}$ in each treatment in triplicates. After the removing of gravel and crop residues, all soil samples were air-dried and passed through a $1 \mathrm{~mm}$ sieve.

The soil permeability was measured using a permeability cylinder, and the measured permeability is its value at a temperature $10^{\circ} \mathrm{C}$, expressed as $\mathrm{K}_{10}(\mathrm{~mm} / \mathrm{min})$ (Tian et al., 2013):

$$
K_{10}=K_{t} /(0.7+0.03 t)
$$

where $\mathrm{K}_{10}(\mathrm{~mm} / \mathrm{min})$ is the permeability at $10{ }^{\circ} \mathrm{C}, \mathrm{K}_{\mathrm{t}}(\mathrm{mm} / \mathrm{min})$ is the permeability at $\mathrm{t}$, and $\mathrm{t}$ $\left({ }^{\circ} \mathrm{C}\right)$ is the temperature of infiltrating water at the time of measurement.

On 30 May 2016, the survival rate of Chinese wolfberry seedlings was calculated, while the preservation rate was calculated on 2 May 2017. When the fruits of Chinese wolfberry were mature, the fruits were picked once every seven days. The fruits were collected in each plot and dried in a $45^{\circ} \mathrm{C}$ oven, and the yield of Chinese wolfberry in every plot can be measured. The survival rate and preservation rate were calculated as follows:

$$
\begin{gathered}
\text { Survival rate }=\frac{\text { Actualalive number in the first year }}{\text { Seedling number }} 100 \% \\
\text { Preservation rate }=\frac{\text { Actualalive number in the second year }}{\text { Seedling number }} 100 \%
\end{gathered}
$$

\section{Data processing}

Using an analytical approach of membership functions in fuzzy mathematics (Zhang, 2014), the membership values of various physical and chemical indexes were accumulated for different treatments and the average value was calculated. The values 
were then compared between different treatments to evaluate the improvement effects on alkalized solonchak.

The membership function $\mathrm{X}(\mathrm{u})$ of each index is determined using the following formula:

$$
X(u)=\left\{\begin{array}{l}
\frac{X-X_{\min }}{X_{\max }-X_{\min }} \quad \text { Positive correlation between index and improvement effect } \\
1-\frac{X-X_{\min }}{X_{\max }-X_{\min }} \text { Negative correlation between index and improvement effect }
\end{array}\right.
$$

where $\mathrm{X}(\mathrm{u})$ is the value of the membership function of an index for different treatments, $\mathrm{X}$ is the measured value of an index for different treatments, $\mathrm{X}_{\max }$ is the maximum measured value of an index between all treatments, and $X_{\min }$ is the minimum measured value of an index between all treatments.

All the statistical tests were performed using SPSS software (version 19.0, USA).

\section{Results}

\section{Soil permeability}

The effect of different treatments on the permeability of soil from 0 to $40 \mathrm{~cm}$ is shown in Figure 2. It can be seen from Figure 2 that the control site had a lower permeability compared to the other experimental sites, where its $\mathrm{K}_{10}$ was only $0.25 \pm 0.02 \mathrm{~mm} / \mathrm{min}$ in the first year. Each treatment significantly increased the soil permeability measured in terms of $\mathrm{K}_{10}$ values compared to the control site. The increase in treatment $\mathrm{T} 2$ by $308.0 \%\left(\mathrm{~K}_{10}=1.02 \pm 0.01 \mathrm{~mm} / \mathrm{min}\right)$ is the largest while $\mathrm{T} 7$ increased the least $\left(\mathrm{K}_{10}=0.55 \pm 0.02 \mathrm{~mm} / \mathrm{min}\right)$ in the first year. The permeability of the soil following the treatments in the second year was better in all treatments than the first year.

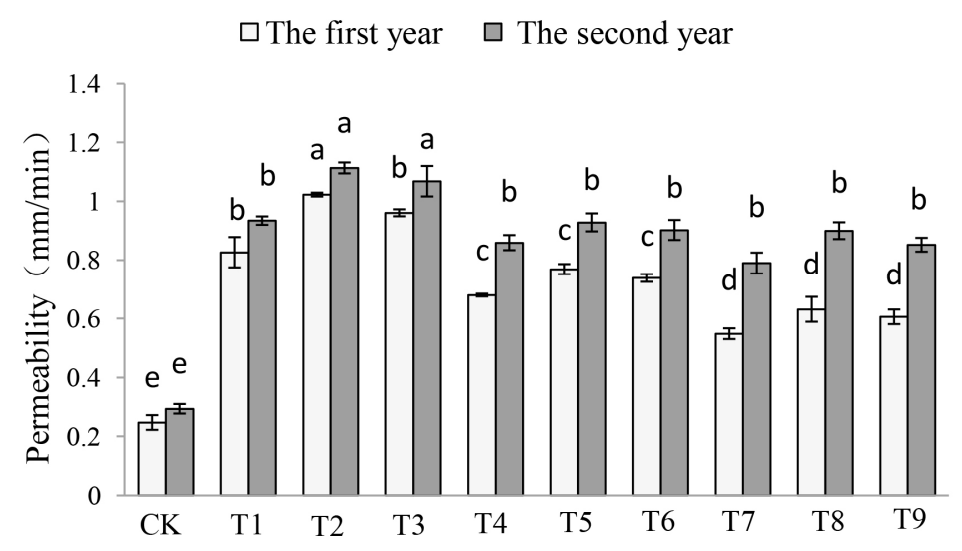

Figure 2. Effect of different treatments on permeability of the soil from $0-40 \mathrm{~cm}$, in which different letters indicate significant differences among treatments $(P \leq 0.05)$ and values $=$ mean \pm standard error, $n=3$

Regarding the blind ditch spacing, it is clearly to notice in Figure 2 that, a 6-m blind ditch spacing treatments (T1, T2 and T3) have the highest values of soil permeability 
and followed by a 9-m spacing treatments (T4, T5 and T6), which have also superiority on a 12-m spacing treatments (T7, T8 and T9).

Respecting to the DG application rate, Figure 2 shows that the DG application with a $22 \mathrm{t} / \mathrm{hm}^{2}$ (T2, T5 and T8) gives rise to the highest soil permeability as compared with the other treatments $\left(20 \mathrm{t} / \mathrm{hm}^{2}\right.$ and $24 \mathrm{t} / \mathrm{hm}^{2} \mathrm{DG}$ application rate). In addition, $\mathrm{T} 2$ in the second year shows the highest improvement in soil permeability $\left(\mathrm{K}_{10}=1.11 \pm 0.02 \mathrm{~mm} / \mathrm{min}\right)$.

\section{Soil pH}

The effect of each treatment on $\mathrm{pH}$ of the soil from 0 to $40 \mathrm{~cm}$ is shown in Figure 3.

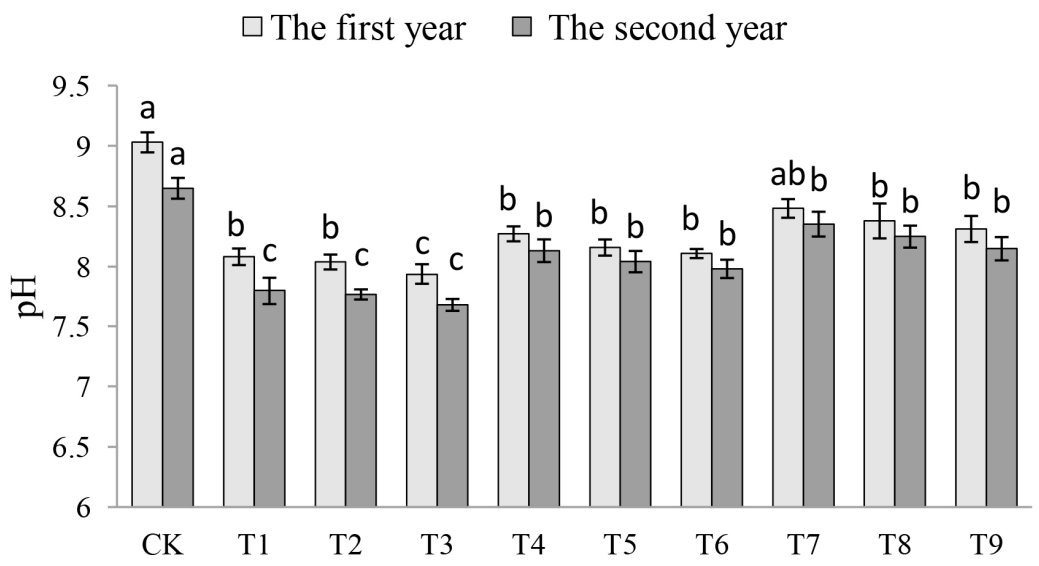

Figure 3. Effects of different treatments on the pH of soil from $0-40 \mathrm{~cm}$, in which different letters indicate significant differences among treatments $(P \leq 0.05)$ and values $=$ mean \pm standard error, $n=3$

Figure 3 illustrates that $\mathrm{pH}$ values of other treatment are lower than that of the control site except $\mathrm{T} 7$, and $\mathrm{pH}$ of $\mathrm{T} 3$ decreased by $12.1 \%$ compared to the control site in the first year. T3 in the second year has the minimum $\mathrm{pH}(7.7 \pm 0.05)$. The $\mathrm{pH}$ of treatments with blind ditch spacing of $6-\mathrm{m}, 9-\mathrm{m}$ and $12-\mathrm{m}$ in the first year on average decreased by $9.9 \%, 8.1 \%$ and $5.7 \%$, respectively, compared to those before the treatments. In the second year, the $\mathrm{pH}$ of treatments with blind ditch spacing of 6-m, 9$\mathrm{m}$ and $12-\mathrm{m}$ on average decreased by $13.0 \%, 9.5 \%$ and $7.3 \%$, respectively, compared to those before the treatments. It clear that the blind ditch with smaller spacing is more effective to reduce the soil $\mathrm{pH}$ compared to the other treatments.

Respecting to the DG application rate, Figure 3 show that the DG application with a $24 \mathrm{t} / \mathrm{hm}^{2}$ (T3, T6 and T9) produced the lowest $\mathrm{pH}$ compared to other treatments $\left(20 \mathrm{t} / \mathrm{hm}^{2}\right.$ and $22 \mathrm{t} / \mathrm{hm}^{2}$ DG application rate).

\section{Exchangeable sodium percentage (ESP)}

The effect of each treatment on the ESP of the soil from 0 to $40 \mathrm{~cm}$ is illustrated in Figure 4. It is seen from Figure 4 that the ESP of each treatment is lower than that of the control site, and the ESP of T3 has the largest decrease of $51.0 \%$ than that before the treatment in the first year. 
The ESP of treatments with blind ditch spacing of 6-m, 9-m and 12-m in the first year on average decreased by $47.5 \%, 40.5 \%$ and $37.4 \%$, respectively, compared to those before the treatments. In the second year, the ESP of treatments with blind ditch spacing of $6-\mathrm{m}, 9-\mathrm{m}$ and $12-\mathrm{m}$ on average decreased by $52.8 \%, 45.5 \%$ and $41.6 \%$, respectively, compared to those before the treatments. Regarding the blind ditch spacing, it is clearly to notice in Figure 4 that, a 6-m blind ditch spacing treatments have the lowest values of ESP, compared to 9-m and 12-m spacing treatments.

According to the DG application rate, Figure 4 shows that the DG application with a $24 \mathrm{t} / \mathrm{hm}^{2}$ (T3, T6 and T9) produced the lowest ESP compared to other treatments (20 t/hm $\mathrm{hm}^{2}$ and $22 \mathrm{t} / \mathrm{hm}^{2}$ DG application rate). In addition, T3 in the second year had the lowest ESP $(11.8 \pm 0.09 \%)$.

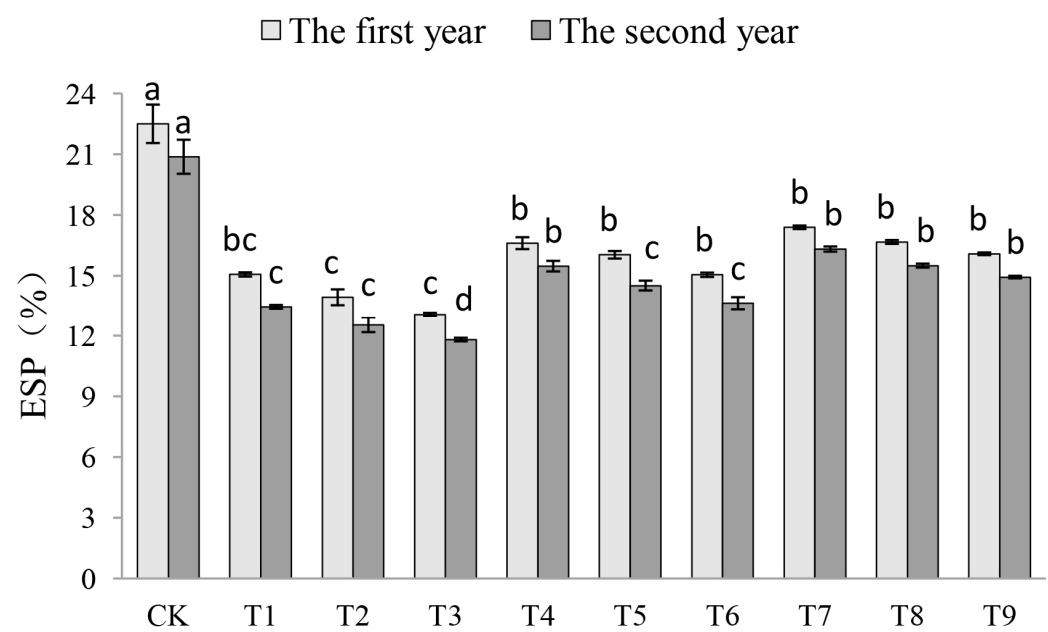

Figure 4. Effects of different treatments on ESP of soil from 0-40 cm, in which different letters indicate significant differences among treatments $(P \leq 0.05)$ and values $=$ mean \pm standard error, $n=3$

\section{Electrical conductivity (EC)}

Before the soil improvement, the EC values of soil layers at 0 to $20 \mathrm{~cm}, 20$ to $40 \mathrm{~cm}$ and 40 to $60 \mathrm{~cm}$ were $2.89 \mathrm{dS} / \mathrm{m}, 2.72 \mathrm{dS} / \mathrm{m}$ and $1.83 \mathrm{dS} / \mathrm{m}$, respectively. The effect of each treatment on EC values in the soil layer from 0 to $60 \mathrm{~cm}$ is illustrated in Figure 5. As shown in Figure $5 a$, in the first year salts in the layers at 0 to $60 \mathrm{~cm}$ of each treatment were leached and the desalination effect on the land surface was significant. The EC values of the control site at 0 to $60 \mathrm{~cm}$ depth gradually increased with the soil depth in the first year. Salt accumulation indicated by an EC reading higher than its original value appeared at the depth of 40 to $60 \mathrm{~cm}$. As to the data in Figure $5 \mathrm{~b}$ for the second year, the EC value was highest at 0 to $20 \mathrm{~cm}$ of the control site. Treatments $\mathrm{T} 1$ to T9 did not appear to generate any secondary salinization. This is approved that, subsurface gravel blind ditches technique clearly leached the salts from soil layers and desalination effect on the land surface was significant.

In the first year, the EC of T2 at the 0 to $20 \mathrm{~cm}$ soil depth declined the most $(75.1 \%)$ following the improvement. There were no significant differences for T1, T2, T3, T4, T5 and T6 at 0 to $20 \mathrm{~cm}, 20$ to $40 \mathrm{~cm}$ and 40 to $60 \mathrm{~cm}$ soil depths in the first and second years. In the first year, the EC values of T1, T2, T3, T4, T5, T6, T7, T8 and T9 
decreased by $40.1 \%, 45.4 \%, 42.3 \%, 33.7 \%, 37.4 \%, 35.4 \%, 19.5 \%, 23.9 \%$ and $22.0 \%$ at 0 to $60 \mathrm{~cm}$, respectively, compared to the control site. In the second year, the EC values of T1, T2, T3, T4, T5, T6, T7, T8 and T9 decreased by 49.4\%, 55.2\%, 52.2\%, 42.5\%, $47.7 \%, 45.1 \%, 32.5 \%, 37.2 \%$ and $34.9 \%$ at 0 to $60 \mathrm{~cm}$, respectively, compared to the control site.

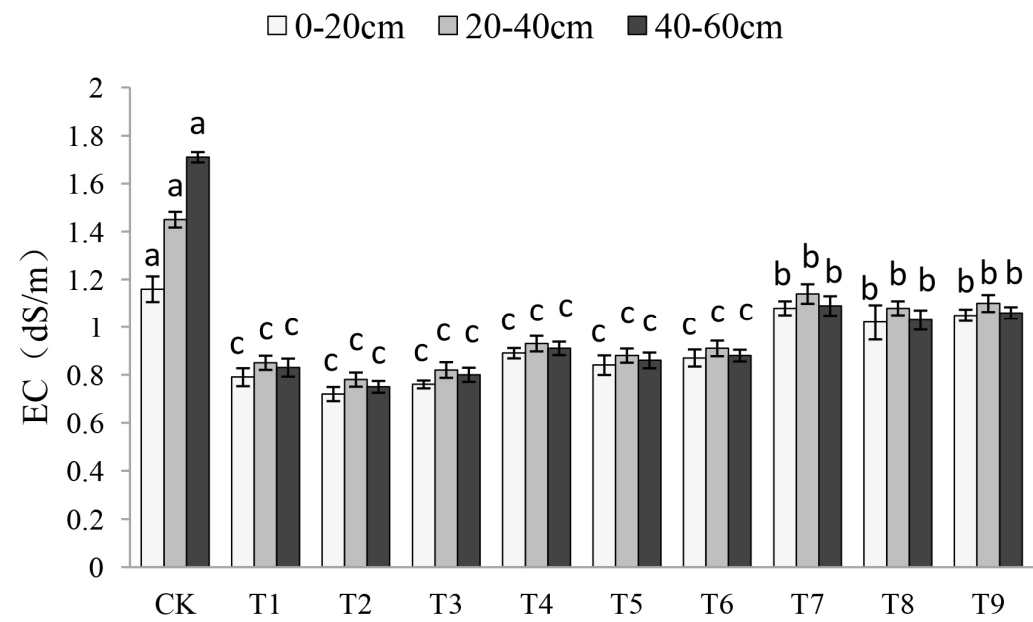

a. First year

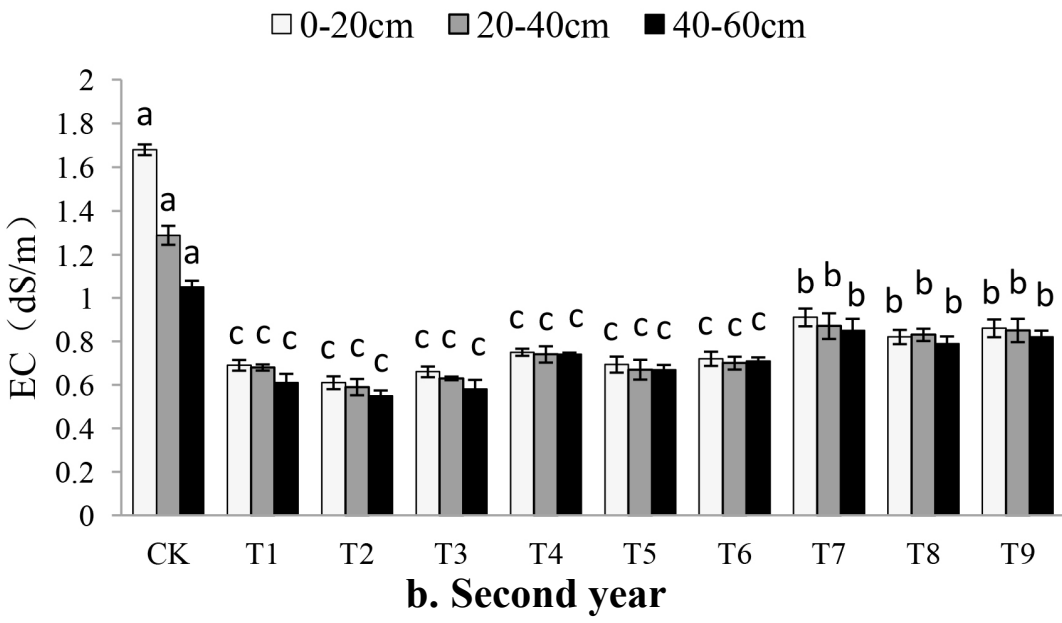

Figure 5. Effects of different treatments on EC value of soil from $0-60 \mathrm{~cm}$, in which different letters indicate significant differences among treatments $(P \leq 0.05)$ and values $=$ mean \pm standard error, $n=3$

\section{Soil salt ions}

The effect of each treatment on ions is illustrated in Table 3. The concentrations of $\mathrm{Na}^{+}, \mathrm{Cl}^{-}, \mathrm{CO}_{3}^{2-}, \mathrm{HCO}_{3}^{-}$of the soil significantly declined following the treatment, and $\mathrm{Mg}^{2+}, \mathrm{K}^{+}$did not change after the treatment while the concentration of $\mathrm{SO}_{4}^{2-}$ increased. The concentration of $\mathrm{Ca}^{2+}$ in each treatment was higher than that on the control site. The concentration of $\mathrm{Na}^{+}$declined over $60 \%$ in the first year following the treatment, and declined over $75 \%$ in the second year following the treatment compared to those before the treatments. The concentration of $\mathrm{Na}^{+}$in $\mathrm{T} 3 \mathrm{had}$ the largest decrease. $\mathrm{CO}_{3}^{2-}$ and $\mathrm{HCO}^{-3}$ of T3 decreased the most in the first year by $49.1 \%$ and $51.8 \%$, respectively, compared 
to those before the treatments. In the second year, the concentrations of $\mathrm{CO}_{3}^{2-}$ and $\mathrm{HCO}_{3}^{-}$ of $\mathrm{T} 3$ were $0.01 \mathrm{cmol} / \mathrm{kg}$ and $0.04 \mathrm{cmol} / \mathrm{kg}$, respectively, and continued decreasing compared with the first year.

In the first year, the concentrations of $\mathrm{Cl}^{-}$in nine treatments were lower than $0.09 \mathrm{cmol} / \mathrm{kg}, \mathrm{Cl}^{-}$of $\mathrm{T} 3$ decreased the most by $95.4 \%$ compared to that before the improving treatments. In the second year, the concentrations of $\mathrm{Cl}^{-}$in nine treatments were lower than $0.07 \mathrm{cmol} / \mathrm{kg}$, and continued the decrease compared with the first year.

In the first year, DG was applied to increase the concentrations of $\mathrm{Ca}^{2+}$ and $\mathrm{SO}_{4}^{2-}$, which had the greatest increase in T9, by $133.3 \%$ and $47.4 \%$, respectively, comparing with before improvement. The data illustrated that the concentrations of $\mathrm{Ca}^{2+}$ in each treatment was higher than that on the control site, and the concentrations of $\mathrm{Ca}^{2+}$ and $\mathrm{SO}$ ${ }_{4}^{2-}$ of $\mathrm{T} 1 \mathrm{were} 0.25 \mathrm{cmol} / \mathrm{kg}$ and $0.72 \mathrm{cmol} / \mathrm{kg}$, respectively, which were the lowest in the nine treatments in the second year. Compared to the control site, the difference in $\mathrm{Mg}^{2+}$ and $\mathrm{K}^{+}$concentrations of each treatment were insignificant in both first and second years.

Table 3. Effect of different treatments on the distribution of salt ions in $0-40 \mathrm{~cm}$ soil layer $(\mathrm{cmol} / \mathrm{kg})$

\begin{tabular}{|c|c|c|c|c|c|c|c|c|c|}
\hline Year & reatment & $\mathbf{N a}^{+}$ & $\mathrm{Ca}^{2+}$ & $\mathrm{Mg}^{2+}$ & $\mathbf{K}^{+}$ & $\mathrm{CO}_{3}^{2-}$ & $\mathrm{HCO}_{3}^{-}$ & $\mathrm{Cl}^{-}$ & $\mathbf{S O}_{4}^{2-}$ \\
\hline \multirow{10}{*}{2016} & $\mathrm{CK}$ & $49 \pm 0.16^{\mathrm{a}}$ & $0.33 \pm 0.04^{\mathrm{c}}$ & $0.24 \pm 0.04^{\mathrm{a}}$ & $0.07 \pm 0.02^{\mathrm{a}}$ & $0.94 \pm 0.07^{\mathrm{a}}$ & $0.87 \pm 0.09^{\mathrm{a}}$ & $0.15 \pm 0.04^{\mathrm{a}}$ & $1.12 \pm 0.09^{d}$ \\
\hline & $\mathrm{T} 1$ & & $0.52 \pm 0.05^{\mathrm{b}}$ & $0.23 \pm 0.04^{\mathrm{a}}$ & $0.08 \pm 0.01^{\mathrm{a}}$ & $0.67 \pm 0.04^{b}$ & $0.55 \pm 0.06^{\mathrm{b}}$ & $0.08 \pm 0.01^{b}$ & $1.45 \pm 0.08^{\mathrm{c}}$ \\
\hline & $\mathrm{T} 2$ & $1.19 \pm 0.06^{\mathrm{c}}$ & $0.59 \pm 0.08^{\mathrm{ab}}$ & $0.19 \pm 0.03^{\mathrm{a}}$ & $0.07 \pm 0.01^{\mathrm{a}}$ & $0.64 \pm 0.07^{b}$ & $0.55 \pm 0.07^{b}$ & $0.07 \pm 0.01^{b}$ & $1.51 \pm 0.05^{\mathrm{b}}$ \\
\hline & $\mathrm{T} 3$ & & $0.64 \pm 0.07^{\mathrm{a}}$ & $0.18 \pm 0.02^{\mathrm{a}}$ & $0.08 \pm 0.00^{\mathrm{a}}$ & $0.56 \pm 0.04^{b}$ & $0.53 \pm 0.07^{b}$ & $0.06 \pm 0.01^{b}$ & $1.57 \pm 0.07^{\mathrm{ab}}$ \\
\hline & $\mathrm{T} 4$ & $1.38 \pm 0.07^{\mathrm{b}}$ & $0.54 \pm 0.03^{b}$ & $21 \pm 0.03^{\mathrm{a}}$ & $0.09 \pm 0.01^{\mathrm{a}}$ & $0.68 \pm 0.06^{b}$ & $0.56 \pm 0.06^{b}$ & $0.08 \pm 0.02^{\mathrm{b}}$ & $1.46 \pm 0.06^{\mathrm{c}}$ \\
\hline & T5 & $1.21 \pm 0.11^{\mathrm{bc}}$ & $0.63 \pm 0.04^{\mathrm{a}}$ & $0.19 \pm 0.02^{\mathrm{a}}$ & $0.08 \pm 0.01^{\mathrm{a}}$ & $0.65 \pm 0.06^{\mathrm{b}}$ & $0.56 \pm 0.05^{b}$ & $0.08 \pm 0.02^{b}$ & $1.54 \pm 0.05^{\mathrm{b}}$ \\
\hline & T6 & $1.07 \pm 0.05^{\mathrm{e}}$ & $0.68 \pm 0.04^{\mathrm{a}}$ & $0.19 \pm 0.03^{\mathrm{a}}$ & $0.08 \pm 0.00^{\mathrm{a}}$ & $0.62 \pm 0.06^{b}$ & $0.53 \pm 0.05^{b}$ & $0.09 \pm 0.02^{b}$ & $1.60 \pm 0.03^{\mathrm{a}}$ \\
\hline & $\mathrm{T} 7$ & $1.36 \pm 0.04^{\mathrm{b}}$ & $0.57 \pm 0.09^{b}$ & $0.21 \pm 0.03^{\mathrm{a}}$ & $0.08 \pm 0.01^{\mathrm{a}}$ & $0.69 \pm 0.07^{b}$ & $0.58 \pm 0.09^{b}$ & $0.09 \pm 0.02^{b}$ & $1.51 \pm 0.06^{\mathrm{b}}$ \\
\hline & $\mathrm{T} 8$ & $1.15=$ & $0.65 \pm 0.02^{\mathrm{a}}$ & $0.23 \pm 0.04^{\mathrm{a}}$ & $0.09 \pm 0.01^{\mathrm{a}}$ & $0.68 \pm 0.06^{b}$ & $0.57 \pm 0.09^{b}$ & $0.08 \pm 0.03^{b}$ & $1.63 \pm 0.12^{\mathrm{a}}$ \\
\hline & T9 & 1.12 & $0.70 \pm 0.02^{\mathrm{a}}$ & $0.22 \pm 0.05^{\mathrm{a}}$ & $0.08 \pm 0.02^{\mathrm{a}}$ & $0.66 \pm 0.07^{b}$ & $0.54 \pm 0.06^{\mathrm{b}}$ & $0.08 \pm 0.02^{b}$ & $1.68 \pm 0.05^{\mathrm{a}}$ \\
\hline \multirow{10}{*}{2017} & $\mathrm{CK}$ & & $05^{\mathrm{a}}$ & $0.23 \pm 0.05^{\mathrm{a}}$ & $0.08 \pm 0.01^{\mathrm{a}}$ & $0.85 \pm 0.11^{\mathrm{a}}$ & $0.12 \pm 0.04^{\mathrm{a}}$ & $0.11 \pm 0.05^{\mathrm{a}}$ & $1.06 \pm 0.03^{\mathrm{a}}$ \\
\hline & $\mathrm{T} 1$ & $0.81 \pm 0.05^{b}$ & $0.35 \pm 0.05^{\mathrm{a}}$ & $0.24 \pm 0.06^{\mathrm{a}} \mid$ & $0.06 \pm 0.01^{\mathrm{a}}$ & $0.03 \pm 0.01^{\mathrm{b}}$ & $0.09 \pm 0.03^{\mathrm{ab}}$ & $0.05 \pm 0.02^{b}$ & $0.72 \pm 0.09^{c}$ \\
\hline & $\mathrm{T} 2$ & & $0.30 \pm 0.05^{\mathrm{a}}$ & $0.20 \pm 0.05^{\mathrm{a}}$ & $0.07 \pm 0.01^{\mathrm{a}}$ & $0.03 \pm 0.01^{b}$ & $0.05 \pm 0.02^{b}$ & $0.04 \pm 0.01^{b}$ & $0.78 \pm 0.07^{\mathrm{c}}$ \\
\hline & $\mathrm{T} 3$ & & $0.33 \pm 0.04^{\mathrm{a}}$ & $0.19 \pm 0.06^{\mathrm{a}}$ & $0.07 \pm 0.01^{\mathrm{a}}$ & $0.01 \pm 0.00^{\mathrm{b}}$ & $0.04 \pm 0.01^{b}$ & $0.03 \pm 0.01^{b}$ & $0.82 \pm 0.04^{\mathrm{b}}$ \\
\hline & $\mathrm{T} 4$ & & $0.30 \pm 0.02^{\mathrm{a}}$ & $0.22 \pm 0.05^{\mathrm{a}}$ & $0.08 \pm 0.01^{\mathrm{a}}$ & $0.03 \pm 0.01^{b}$ & $0.09 \pm 0.02^{\mathrm{ab}}$ & $0.05 \pm 0.01^{b}$ & $0.79 \pm 0.02^{\mathrm{c}}$ \\
\hline & T5 & $0.79 \pm 0.10^{\mathrm{bc}}$ & $0.32 \pm 0.02^{\mathrm{a}}$ & $0.20 \pm 0.06^{\mathrm{a}}$ & $0.07 \pm 0.01^{\mathrm{a}}$ & $0.04 \pm 0.00^{\mathrm{b}}$ & $0.08 \pm 0.02^{\mathrm{b}}$ & $0.06 \pm 0.01^{b}$ & $0.83 \pm 0.09^{b}$ \\
\hline & T6 & $0.72 \pm 0.08^{b c}$ & $0.35 \pm 0.03^{\mathrm{a}}$ & $0.21 \pm 0.04^{\mathrm{a}}$ & $0.09 \pm 0.01^{\mathrm{a}}$ & $0.03 \pm 0.01^{b}$ & $0.07 \pm 0.01^{\mathrm{b}}$ & $0.06 \pm 0.01^{b}$ & $0.89 \pm 0.07^{b}$ \\
\hline & $\mathrm{T} 7$ & $0.85 \pm 0.10^{b}$ & $0.34 \pm 0.03^{\mathrm{a}}$ & $0.19 \pm 0.02^{\mathrm{a}}$ & $0.07 \pm 0.02^{\mathrm{a}}$ & $0.06 \pm 0.01^{b}$ & $0.10 \pm 0.01^{\mathrm{a}}$ & $0.07 \pm 0.01^{b}$ & $0.86 \pm 0.05^{\mathrm{b}}$ \\
\hline & $\mathrm{T} 8$ & $0.83 \pm 0.10^{b}$ & $0.38 \pm 0.02^{\mathrm{a}}$ & $0.21 \pm 0.03^{\mathrm{a}}$ & $0.08 \pm 0.02^{\mathrm{a}}$ & $0.06 \pm 0.01^{b}$ & $0.09 \pm 0.01^{\mathrm{ab}}$ & $0.06 \pm 0.01^{b}$ & $0.91 \pm 0.03^{b}$ \\
\hline & T9 & $0.83 \pm 0.08^{b}$ & $0.42 \pm 0.02^{\mathrm{a}}$ & $0.22 \pm 0.05^{\mathrm{a}}$ & $0.07 \pm 0.02^{\mathrm{a}}$ & $0.05 \pm 0.02^{\mathrm{b}}$ & $0.09 \pm 0.00^{\mathrm{ab}}$ & $0.06 \pm 0.01^{b}$ & $1.02 \pm 0.05^{\mathrm{a}}$ \\
\hline
\end{tabular}

Different letters indicate significant difference among treatments at 0.05 level

Values $=$ mean \pm standard error, $\mathrm{n}=3$

\section{Analysis of treatments on improvement effects of alkalized solonchak}

Different expressions for evaluating the membership function values are used following a comprehensive analysis of the data from different treatments. The results are shown in Table 4. As shown in Table 4, T2 had the greatest improvement effect on alkalized solonchak among the nine treatments. The soil treatment effect had the following order of improvement: $\mathrm{T} 2>\mathrm{T} 3>\mathrm{T} 1>\mathrm{T} 6>\mathrm{T} 5>\mathrm{T} 4>\mathrm{T} 8>\mathrm{T} 9>\mathrm{T} 7$. The 
results of $\mathrm{T} 1, \mathrm{~T} 2$ and $\mathrm{T} 3$ show that under the condition with 6-m blind ditch spacing, an appropriate DG application rate will have better improvement effects. The results of T3, T6 and T9 show that with $24 \mathrm{t} / \mathrm{hm}^{2}$ of DG application rate, the smaller spacing of blind ditches the better improvement effect.

Table 4. Comprehensive appraisal index of soil improvement effects of different treatments

\begin{tabular}{c|c|c|c|c|c|c|c|c|c}
\hline Index & T1 & T2 & T3 & T4 & T5 & T6 & T7 & T8 & T9 \\
\hline Permeability & 0.784 & 1 & 0.902 & 0.692 & 0.777 & 0.745 & 0.607 & 0.743 & 0.724 \\
pH & 0.876 & 0.943 & 1 & 0.536 & 0.629 & 0.598 & 0.206 & 0.412 & 0.340 \\
EC & 0.878 & 1 & 0.912 & 0.797 & 0.892 & 0.851 & 0.608 & 0.689 & 0.649 \\
ESP & 0.764 & 0.895 & 1 & 0.480 & 0.616 & 0.740 & 0.362 & 0.477 & 0.556 \\
Comprehensive evaluation & 0.826 & 0.960 & 0.954 & 0.627 & 0.728 & 0.734 & 0.446 & 0.580 & 0.567 \\
Sorting & 3 & 1 & 2 & 6 & 5 & 4 & 9 & 7 & 8 \\
\hline
\end{tabular}

\section{Survival rate, height and yield of Chinese wolfberry}

The crop yield is an important index for measuring the productivity of land, and Table 5 lists the effects of different treatments on survival rate, height and yield of Chinese wolfberry. It can be seen from Table 5 that the survival rate and preservation rate on the control site are lowest than other treatments. The seedling survival rate, preservation rate and the yield of Chinese wolfberry increased significantly in nine treatments compared to the control site in the first year. The yields of T1, T2 and T3 increased than those of T4, T5, T6, T7, T8 and T9. The yields of T1, T2 and T3 did not have significant differences. In the first year, the yield of Chinese wolfberry of the treatments with a 6-m blind ditch spacing was higher than those with 9-m and 12-m spacing. The treatment of T2 had the highest yield is $1.08 \mathrm{t} / \mathrm{hm}^{2}$ in the first year, and increased by $78.7 \%$ in the second year than that for the first year.

Table 5. Effects of different treatments on survival rate, height and yield of Chinese wolfberry

\begin{tabular}{c|c|c|c|c|c}
\hline Year & Treatment & $\begin{array}{c}\text { Survival rate } \\
\mathbf{( \% )}\end{array}$ & $\begin{array}{c}\text { Preservation rate } \\
\mathbf{( \% )}\end{array}$ & $\begin{array}{c}\text { Height } \\
(\mathbf{c m})\end{array}$ & $\begin{array}{c}\text { Yield } \\
\left(\mathbf{t} / \mathbf{h m}^{2}\right)\end{array}$ \\
\hline \multirow{5}{*}{ The first year } & CK & $43.3 \pm 2.36^{\mathrm{b}}$ & - & $68.3 \pm 0.78^{\mathrm{c}}$ & $0.49 \pm 0.01^{\mathrm{c}}$ \\
& T1 & $88.3 \pm 4.71^{\mathrm{a}}$ & - & $87.4 \pm 1.07^{\mathrm{b}}$ & $1.03 \pm 0.01^{\mathrm{b}}$ \\
& T2 & $93.3 \pm 2.36^{\mathrm{a}}$ & - & $91.2 \pm 0.78^{\mathrm{b}}$ & $1.08 \pm 0.01^{\mathrm{b}}$ \\
& T3 & $86.7 \pm 4.71^{\mathrm{a}}$ & - & $90.9 \pm 0.34^{\mathrm{b}}$ & $1.04 \pm 0.01^{\mathrm{b}}$ \\
& T4 & $86.7 \pm 2.36^{\mathrm{a}}$ & - & $86.1 \pm 2.64^{\mathrm{b}}$ & $0.94 \pm 0.02^{\mathrm{b}}$ \\
& T5 & $90.0 \pm 4.08^{\mathrm{a}}$ & - & $87.5 \pm 0.78^{\mathrm{b}}$ & $0.99 \pm 0.02^{\mathrm{b}}$ \\
& T6 & $85.0 \pm 4.08^{\mathrm{a}}$ & - & $86.4 \pm 1.02^{\mathrm{b}}$ & $0.96 \pm 0.01^{\mathrm{b}}$ \\
& T7 & $83.3 \pm 2.36^{\mathrm{a}}$ & - & $83.5 \pm 0.79^{\mathrm{b}}$ & $0.91 \pm 0.01^{\mathrm{b}}$ \\
& T8 & $86.7 \pm 2.36^{\mathrm{a}}$ & - & $84.5 \pm 0.75^{\mathrm{b}}$ & $0.95 \pm 0.01^{\mathrm{b}}$ \\
& T9 & $80.0 \pm 4.08^{\mathrm{a}}$ & - & $83.7 \pm 0.39^{\mathrm{b}}$ & $0.92 \pm 0.01^{\mathrm{b}}$ \\
\hline \multirow{5}{*}{ The second year } & - & $40.0 \pm 4.08^{\mathrm{b}}$ & $86.6 \pm 0.76^{\mathrm{c}}$ & $0.59 \pm 0.01^{\mathrm{c}}$ \\
& CK & - & $81.7 \pm 6.24^{\mathrm{a}}$ & $113.8 \pm 1.17^{\mathrm{a}}$ & $1.91 \pm 0.04^{\mathrm{a}}$ \\
& T1 & - & $90.0 \pm 4.08^{\mathrm{a}}$ & $119.8 \pm 1.15^{\mathrm{a}}$ & $1.93 \pm 0.02^{\mathrm{a}}$ \\
& T2 & - & $83.3 \pm 4.71^{\mathrm{a}}$ & $115.6 \pm 0.71^{\mathrm{a}}$ & $1.94 \pm 0.01^{\mathrm{a}}$ \\
\hline
\end{tabular}




\begin{tabular}{l|l|l|l|l|l}
\hline & T4 & - & $85.0 \pm 4.08^{\mathrm{a}}$ & $111.2 \pm 1.64^{\mathrm{a}}$ & $1.89 \pm 0.04^{\mathrm{a}}$ \\
& T5 & - & $88.3 \pm 4.71^{\mathrm{a}}$ & $115.4 \pm 0.88^{\mathrm{a}}$ & $1.91 \pm 0.03^{\mathrm{a}}$ \\
T6 & - & $85.0 \pm 4.08^{\mathrm{a}}$ & $113.5 \pm 0.66^{\mathrm{a}}$ & $1.90 \pm 0.04^{\mathrm{a}}$ \\
& T7 & - & $81.7 \pm 6.24^{\mathrm{a}}$ & $108.9 \pm 1.24^{\mathrm{a}}$ & $1.86 \pm 0.03^{\mathrm{a}}$ \\
& T8 & - & $83.3 \pm 2.36^{\mathrm{a}}$ & $113.7 \pm 0.74^{\mathrm{a}}$ & $1.90 \pm 0.04^{\mathrm{a}}$ \\
& T9 & - & $78.3 \pm 2.36^{\mathrm{a}}$ & $110.8 \pm 1.20^{\mathrm{a}}$ & $1.88 \pm 0.02^{\mathrm{a}}$ \\
\hline
\end{tabular}

The yield of Chinese wolfberry is the yield of dried fruits. Values $=$ mean \pm standard error, $\mathrm{n}=3$. Different letters indicate significant difference among treatments $(P \leq 0.05)$

\section{Discussion}

Alkalized solonchak has a high ESP, and under high alkaline conditions, the ion exchange with $\mathrm{Na}^{+}$during soil cementation results in the increased hydration of the cementing substance causing the soil to peptize and disperse easily in the presence of water (Ahmad et al., 2016). The macropores in the alkaline soils, once wetted, collapse to form fine pores leading to the impedance of soil water movement. The amelioration of saline-alkaline soils reduced both soil $\mathrm{pH}$ and ESP rapidly and effectively (Nan et al., 2016). As $\mathrm{Ca}^{2+}$ can flocculate soil colloids to form water stable aggregates which promote soil water movement (Morillo et al., 2002; Mahdy, 2011), the application of DG increases the concentration of $\mathrm{Ca}^{2+}$ in the soil which increases the capacity of adsorption to soil colloids more than that $\mathrm{Na}^{+}$, thereby playing a role in improving the soil texture. The adsorbed $\mathrm{Na}^{+}$on soil colloids can exchange with $\mathrm{Ca}^{2+}$ in the soil solution, which decreases the exchangeable $\mathrm{Na}^{+}$, thus decreasing soil ESP. Meanwhile, $\mathrm{SO}_{4}^{2-}$ is an acid radical with certain neutralization effects. The concentrations of $\mathrm{CO}_{3}^{2-}$ and $\mathrm{HCO}_{3}^{-}$in the soil are important factors for determining the $\mathrm{pH}$ value of saline-alkaline soils (Chen et al., 2014). Consequently, a decrease in $\mathrm{CO}_{3}^{2-}$ and $\mathrm{HCO}_{3}^{-}$in the soils content results in a decline in soil $\mathrm{pH}$. However, DG is also a moderately soluble salt, which can increase the amount of salt in the soil if DG application rate is too much (Sakai et al., 2011). Therefore, in this experiment, the optimal application rate is $22 \mathrm{t} / \mathrm{hm}^{2}$.

In order to enhance the treatment effects, the clay layer in the deeper soil must be disturbed to increase leaching. A clay layer between $60 \mathrm{~cm}$ and $80 \mathrm{~cm}$ at our experimental site was impervious to water, and collected the leached salts from the soil surface. In this arid region with little rainfall and strong evaporation, salts migrate through soil capillary forces to the surface of the soil leading to a higher EC value on the soil surface. The depth of our blind ditches is up to $120 \mathrm{~cm}$, which broke the clay layer and promoted the migration of soil salts downward. The bottoms of the blind ditches are laid with gravels and straws to change the uniformity of soil texture, and to improve the soil water potential and permeability (Qu and Wang, 1997). Subsurface pipes can capture and drain infiltrating water to enhance desalinization and reduce the EC of the soil (Qu and Wang, 1997; Zhang et al., 2012b). Pores in gravels and straws are larger than those in the soil, and facilitate soil water movement. Our results are consistent with findings from other experiments on the improvement of soil structure with straws (Qu and Wang, 1997) and gravels (Zhang et al., 2012a).

The results presented here also show that soil water concentrates in straws forming a desalting zone after irrigation and expediting the desalting process (Zhen and Hao, 2010). We found that the application of gravels and straws not only accelerates the leaching of soil salts, but also prevents secondary salinization in the second year. Burying gravel and straw in a homogeneous soil can also improve soil aeration and crop 
growth and reduce the upward water movement. In addition, the organic acid released during the decomposition of straws can promote the dissolution of $\mathrm{Ca}^{2+}(\mathrm{Lu}$ et al., 2017).

$\mathrm{Cl}^{-}$has stable chemical properties with slow chemical reactions such as adsorption (Yang et al., 2015a). Yang et al. (2015a) found through an amelioration experiment of alkaline soil that with leaching, $\mathrm{Cl}^{-}$easily accumulates in the soil deeper than $60 \mathrm{~cm}$ from the surface and is difficult to discharge through the soil layers again (Yang et al., 2015a). However, in our research, the concentrations of $\mathrm{Cl}^{-}$for all treatments were significantly reduced, proving that the blind ditches help discharge $\mathrm{Cl}^{-}$. The application of DG will increase the concentration of $\mathrm{SO}_{4}^{2-}, \mathrm{SO}_{4}^{2-}$ and $\mathrm{Na}^{+}$producing $\mathrm{Na}_{2} \mathrm{SO}_{4}$ (Buckley and Wolkowski, 2014), which is leached to blind ditches by irrigation water and discharged from the soil.

\section{Conclusion}

With desulfurized gypsum which can effectively improve physical and chemical properties of alkalized solonchak, subsurface gravel blind ditches can further accelerate the leaching of salts from the soil and ameliorate the soil by improving its chemical and mechanical properties. Subsurface gravel blind ditches promoted the DG amelioration effect, which effectively improves the soil permeability and promotes salt leaching. The ESP, EC and the concentrations of $\mathrm{Na}^{+}, \mathrm{Cl}^{-}, \mathrm{CO}_{3}^{2-}$ and $\mathrm{HCO}_{3}^{-}$in the soils are significantly reduced by the blind ditches and DG. Chinese wolfberry yield was significantly increased by the treatments. The best design scenario is one which has $6-\mathrm{m}$ blind ditch spacing combined with a $22 \mathrm{t} / \mathrm{hm}^{2}$ desulfurization gypsum application rate.

Acknowledgements. This work was supported by the "Major Innovation Projects for Building First-class Universities in China's Western Region" (No. ZKZD2017004). In addition, we would like to thank Dr. Ninghu Su from the James Cook University for his constructive suggestions on the present work.

\section{REFERENCES}

[1] Ahmad, S., Ghafoor, A., Akhtar, M. E. (2016): Implication of gypsum rates to optimize hydraulic conductivity for variable-texture saline-sodic soils reclamation. - Land Degradation \& Development 3: 550-560.

[2] Bigham, J. M. (1965): Methods of soil analysis. - American Potato Journal 11: 345-346.

[3] Buckley, M., Wolkowski, R. (2014): In-season effect of flue gas desulfurization gypsum on soil physical properties. - Journal of Environmental Quality 1: 322-327.

[4] Christen, E., Skehan, D. (2001): Design and management of subsurface pipe drainage to reduce salt loads. - Journal of Irrigation \& Drainage Engineering 3: 148-155.

[5] Chi, C. M., Wang, Z. C. (2014): Saturated hydraulic conductivity and its influence factors of saline-alkali soils. - Chinese Journal of Soil Science 3: 601-607 (in Chinese).

[6] Chen, J. R., Chen, X. H., Liu, Z. H. (2014): The experimental study on the process and effect to the FGD-gypsum as an improvement in coastal saline-alkali soil. - China Environmental Science 6: 1505-1513 (in Chinese).

[7] Chen, X., Kang, Y. H., Wan, S. Q. (2015): Influence of mulches on urban vegetation construction in coastal saline land under drip irrigation in North China. - Agricultural Water Management 158: 145-155.

[8] Cucci, G., Lacolla, G., Mastro, M. A. (2016): Leaching effect of rainfall on soil under four-year saline water irrigation. - Soil \& Water Research 11: 181-189. 
[9] Driessen, P., Deckers, J., Spaargaren, O. (2000): Lecture notes on the major soils of the world. - Food and Agriculture Organization (FAO).

[10] De Sutter, T., Cihacek, L., Rahman, S. (2014): Application of flue gas desulfurization gypsum and its impact on wheat grain and soil chemistry. - Journal of Environmental Quality 1: 303-311.

[11] Feng, D., Wan, S. Q., Kang, Y. H. (2017): Drip irrigation scheduling for annual crops in an impermeable saline-sodic soil with an improved method. - Journal of Soil and Water Conservation $4:$ 351-360.

[12] Heng, T., Liao, R. K., Wang, Z. H. et al. (2018): Effects of combined drip irrigation and sub-surface pipe drainage on water and salt transport of saline-alkali soil in Xinjiang, China. - Journal of Arid Land 6: 932-945.

[13] Kameli, M. A., Chorom, M., Jaafarzadeh, N. et al. (2017): Application of wastewater with high organic load for saline-sodic soil reclamation focusing on soil purification ability. - Global Journal of Environmental Science \& Management 3: 197-206.

[14] Lin, Y. L., Li, Y. J., Chen, Y. H. (2016): Effects adding sand on soil physical and chemical property and corn yield in alkalized solonchak soil. - Soil and Fertilizer Sciences 1: 119-123 (in Chinese).

[15] Liu, J. H., Ali, A., Yu, M. F. et al. (2015): Risk evaluation of main pests and integrated management in Chinese wolfberry, Lycium barbarum L. - Pakistan Journal of Zoology 47: 21-29.

[16] Lu, P. R., Zhang, Z. Y., Feng, G. X. (2017): Effect of straw draining piece depth in soil on soil water-salt distribution in saline soil and its drainage-salt inhibiting performance. Transactions of the Chinese Society of Agricultural Engineering 5: 115-121 (in Chinese).

[17] Mahdy, A. M. (2011): Comparative effects of different soil amendments on amelioration of saline-sodic soils. - Soil and Water Research - UZEI (Czech Republic) 4: 205-216.

[18] Mao, Y. M., Li, X. P., Warren, A. D. (2016): Remediation of saline-sodic soil with flue gas desulfurization gypsum in a reclaimed tidal flat of southeast China. - Journal of Environmental Sciences 45: 224-232.

[19] Morillo, E., Maqueda, C., Reinoso, R. (2002): Effect of two organic amendments on norflurazon retention and release by soils of different characteristics. - Environmental Science \& Technology 20: 4319-4325.

[20] Min, W., Hou ZA, Ma, L. J. et al. (2014): Effects of water salinity and N application rate on water- and N-use efficiency of cotton under drip irrigation. - Journal of Arid Land 4: 454-467.

[21] Mohsenian, Y., Roosta, H. (2015): Effects of grafting on alkali stress in tomato plants: datura rootstock improve alkalinity tolerance of tomato plants. - Journal of Plant Nutrition 1: 51-72.

[22] Nan, J., Chen, X., Chen, C. (2016): Impact of flue gas desulfurization gypsum and lignite humic acid application on soil organic matter and physical properties of a saline-sodic farmland soil in Eastern China. - Journal of Soils \& Sediments 9: 1-11.

[23] Pan, P., Zhao, T. (1998): The study of simple blind ditch improvement of saline soil. Ningxia Agriculture and Forestry Technology 3: 28-30 (in Chinese).

[24] Qu, C. X., Wang, W. (1997): Mechanisms of water reserved by sand interlayer in soil profile. - Journal of Huazhong Agricultural University 5: 43-50 (in Chinese).

[25] Qadir, M., Oster, J. D. (2004): Crop and irrigation management strategies for saline-sodic soils and waters aimed at environmentally sustainable agriculture. - Science of the Total Environment 1: 1-19.

[26] Rhoton, F., McChesney, D. (2011): Effect of FGD gypsum on the properties of a highly erodible soil under conservation Tillage. - Communications in Soil Science \& Plant Analysis 16: 2012-2023.

[27] Sakai, Y., Matsumoto, S., Sadakata, M. (2004): Alkali soil reclamation with flue gas desulfurization gypsum in China and assessment of metal content in corn grains. - Soil and Sediment Contamination 1: 65-80. 
[28] Sakai, Y., Ren, S. H., Wang, C. (2011): Salt-affected soil amelioration with flue gas desulfurization by-products and waste gypsum board in Tianjin, China. - Journal of Chemical Engineering of Japan 10: 750-756.

[29] Tian, Y. F., Dou, S., Zhang, Y. G. (2013): Improvement effects of subsurface pipe with different spacing on sodic-alkali soil. - Transactions of the Chinese Society of Agricultural Engineering 12: 145-153 (in Chinese).

[30] Tao, Y., Wang, S. L., Xu, D. (2016): Experimental study of clogging defense measures for improved subsurface drainage. - Transactions of the Chinese Society for Agricultural Machinery 6: 187-192 (in Chinese).

[31] Vance, G., King, L., Ganjegunte, G. (2008): Soil and plant responses from land application of saline-sodic waters: implications of management. - Journal of Environmental Quality 1: 139-148.

[32] Xue, Z., Wan, S. Q., Kang, Y. H. (2014): Effect of sand-filled depth and straw mulching on crops growth in takyric solonetz. - Journal of Irrigation \& Drainage 1: 38-41.

[33] Yang, J., Sun, Z. J., Luo, C. K. (2015a): Effect of salt-water regulation on improving takyric solonetz land and yield of oil sunflower. - Transactions of the Chinese Society of Agricultural Engineering 18: 121-128 (in Chinese).

[34] Yang, Y. C., Pan, D. F., Zou, Z. G. (2015a): Experiment of blind ditch of rice straw in Jiangsu coastal saline soil. - Jiangsu Agricultural Science 3: 373-375 (in Chinese).

[35] Yu, H. L., Gu, W., Tao, J. (2015): Impact of addition of FGDB as a soil amendment on physical and chemical properties of an alkali soil and crop yield of maize in Northern China Coastal Plain. - Journal of Chemistry 8: 1-11.

[36] Yu, S. H., Liu, J. T., Li, Z. X. (2012): Mechanism of saline-alkali lands improvement of subsurface pipe drainage systems and agro-ecosystem response. - Chinese Journal of Eco-Agriculture 12: 1664-1672.

[37] Zhen, W., Hao, F. (2010): Effect of straw-incorporation on soil infiltration characteristics and soil water holding capacity. - Transactions of the Chinese Society of Agricultural Engineering 4: 75-80.

[38] Zhang, J., Chang, T. T., Shao, X. H. (2012a): Improvement effect of subsurface drainage on secondary salinization of greenhouses oil and tomato yield. - Transactions of the Chinese Society of Agricultural Engineering 3: 81-86 (in Chinese).

[39] Zhang, T. B., Kang, Y. H., Hu, W. (2012b): Study on salinity characteristics of takyric solonetz in Ningxia Yinbei region. - Soils 6: 1001-1008 (in Chinese).

[40] Zhang, P. (2014): Effect of Different Afforestation Tree Species on Soil Physical and Chemical Properties of Saline-Alkali Soil. - Shandong Agricultural University, Shandong (in Chinese). 